\title{
EFFECTIVENESS OF USE OF COOPERATIVE LEARNING NUMBERED HEADS TOGETHER (NHT) LEARNING MODEL ON MATHEMATICS LEARNING OUTCOMES OF STUDENTS IN SMP N 1 SRANDAKAN
}

\author{
Erny Setyaningsih ${ }^{\mathrm{a}}$, Sumargiyani ${ }^{\mathrm{b}}$ \\ Program Studi Pendidikan Matematika Universitas Ahmad Dahlan \\ Jalan Ring Road Selatan, Tamanan, Banguntapan, Bantul Yogyakarta \\ aernysetyaningsih6@gmail.com, ${ }^{\text {b }}$ sumargiyani04@yahoo.com
}

\begin{abstract}
The selection of learning models that are less precise can affect student learning success. Learning in SMP N 1 Srandakan is still centered on the teacher so students tend to be passive in class. This study aims to determine whether there are differences in students' mathematics learning outcomes by using the NHT type of cooperative learning models as well as knowing the effectiveness of the NHT type cooperative learning models for student mathematics learning outcomes. The design of this study is Subjects Posttest Only Control Group Design. The population in this study were students of class VIII of SMP N 1 Srandakan Regency of Bantul in the 2015/2015 academic year with a total of 190 students. Samples in this study were taken using a random sampling technique obtained by class VIII D as an experimental class and class VIII E as a control class. Data collection is done by the test method. Testing instruments using the test the validity of the different power tests and reliability tests. Data analysis techniques using analysis prerequisite tests include normality test with Chi-Square formula, homogeneity test with Bartlett test, and hypothesis testing with t-test. Based on calculations with a significant level $\alpha=5 \%$ and degrees of freedom 62 , it can be concluded that: (1) There are differences in mathematics learning outcomes between students who use the NHT type of cooperative learning models and students who use the direct learning model. This is indicated by the results of the first hypothesis test that $t_{\text {count }}=2.3802$ and $t_{\text {table }}=1.99897$, so $t_{\text {count }}>t_{\text {table }}$. (2) The NHT type of cooperative learning model is more effective than the direct learning model. This is shown from the results of the second hypothesis test that $t_{\text {count }}=2.3802$ and $t_{\text {table }}=1.6698$, so $t_{\text {count }}>t_{\text {table }}$
\end{abstract}

Keywords: Effectiveness, Mathematics, NHT.

\section{INTRODUCTION}

Education is important for all circles of society. All parties must realize the human need for survival. According to Law number 20 of 2003 concerning the National Education System states that education is a conscious and planned effort to create an atmosphere of learning and learning process so that students actively develop their potential to have religious-spiritual strength, self-control, personality, intelligence, noble character, and skills for themselves, society, nation, and country. Along with global challenges, the challenges of the education world are even greater. This triggers students to excel. One of the students' achievements can be seen in the results of learning mathematics. Mathematics grows and develops because of the thought process. Therefore, logical thinking is the basis for the formation of mathematics. In everyday life, mathematics is very useful. Since SD / MI, SMP / MTs, and SMA / SMK / MA, mathematics exists so mathematics is a gradual science. The indicator of the low learning outcomes of mathematics can be seen from the data of the daily test scores for the even semester of class VIII of SMP Negeri 1 Srandakan in the 2015/2016 Academic Year, presented in table 1 below. 
Table 1. Mathematical Daily Test Score with Material Cubes and Beams Grade VIII Students of SMP N 1 Srandakan Even Semester 2015/2016 Academic Year

\begin{tabular}{|l|c|c|c|c|c|c|c|}
\hline Class & VIII A & VIII B & VIII C & VIII D & VIII E & VIII F & Percentage \\
\hline The Highest Score & 67,50 & 60,00 & 60,00 & 65,00 & 65,00 & 92,50 & \\
\hline Lowest Value & 22,50 & 30,00 & 10,00 & 22,50 & 22,50 & 25,00 & \\
\hline Average & 46,37 & 44,03 & 35,97 & 40,29 & 41,40 & 58,39 & \\
\hline $\begin{array}{l}\text { The Number Of } \\
\text { Students Who } \\
\text { Complete KKM }\end{array}$ & 0 & 0 & 0 & 0 & 0 & 3 & $1,57 \%$ \\
\hline $\begin{array}{l}\text { the number of } \\
\text { students who do not } \\
\text { complete KKM }\end{array}$ & 31 & 31 & 32 & 32 & 32 & 29 & $98,43 \%$ \\
\hline
\end{tabular}

Source: SMP Negeri 1 Srandakan

From these data, it is seen that the student mathematics learning outcomes are low. This is known from the number of students who do not complete KKM $(<80)$ more than the number of students who complete KKM $(\geq 80)$. Student learning outcomes can be influenced by several elements, namely the students themselves, the teacher, the environment, infrastructure, curriculum, and learning models applied. Learning models play an important role in the learning process and can even affect learning outcomes. According to Adi, quoted by Suprihatiningrum, Jamil (2013: 142) the learning model is a conceptual framework that describes the procedure in organizing learning experiences to achieve learning objectives. The learning model serves as a guide for teachers in planning and implementing learning activities. According to Suherman, Erman et al. (2003: 7) learning model is intended as a pattern of student interaction with teachers in the classroom regarding the approach strategies, methods, and learning techniques applied in the implementation of teaching and learning activities in class. From some of the above understanding, it can be concluded that the learning model is a pattern of student interaction with the teacher in the classroom to achieve learning objectives.

Based on observations and interviews with students and teachers conducted by researchers at SMP N 1 Srandakan on October 28, 2015, several students stated that mathematics is a difficult and frightening subject. When learning takes place, it is still embarrassing to ask, when the teacher gives questions students do not immediately do the work but the students are busy themselves even talking with friends so that teacher and student interaction is less effective. Based on these observations, the class is more active and effective in learning mathematics if the teacher uses a group / cooperative learning model. Cooperative learning is essentially the same as group work. The theory underlying cooperative learning is the theory of constructivism that was born from the ideas of Piaget and Vigotsky. In this theory, prioritizing student learning faced with problems to find solutions then find the expected skills. According to Nurulhayati, quoted by Rusman (2013: 203), cooperative learning is a learning strategy that involves the participation of students in one small group to interact with one another. According to Ibrahim, Muslim, quoted by Rusman (2013: 208), cooperative learning is a learning activity that uses student learning patterns in groups to establish cooperation and interdependence in the structure of tasks, goals, and prizes. Therefore, cooperative learning is student learning activities in groups to interact with each other and achieve learning goals.

One model of group / cooperative learning is NHT. The NHT type cooperative learning model, first developed by Spenser Kagen. According to Spenser Kagen cited by Suprihatiningrum, Jamil (2013: 209) the NHT learning model is an approach to involve more students in examining the material covered in a lesson and checking their understanding of the contents of the lesson. According to Ahmadi, Lif Khoiru et al. (2011: 59) type NHT cooperative learning is a learning method where each student is given a number then made a group then randomly the teacher calls student number. Therefore, the NHT type of cooperative learning model is a learning method that involves students by following the learning steps. According to Huda, Miftahul (2012: 138), the steps in NHT type learning are students divided into groups, each student is given a number, the teacher gives a task or question and 
each group works on it, the group discussion to find the answers is considered the most correct and ensures that all group members know the answer, and the teacher calls one of the numbers, students with the number called present the answers to the results of their group discussion. In this study, the NHT learning model was chosen because it can provide opportunities for students to mutually express ideas and consider the most appropriate answers and can be used for all subjects and grade levels. Researchers hope that with the support of the learning model, it can improve learning outcomes better.

Based on the background, the problem identification and problem boundary that has been described can be formulated as follows:

1. Are there differences in mathematics learning outcomes of students who use the NHT type cooperative learning model against the results of mathematics learning students who use direct learning models in class VIII students of SMP N 1 Srandakan Bantul Regency even semester of the 2015/2016 school year?

2. Which is more effective between the NHT type of cooperative learning model and the direct learning model of the mathematics learning outcomes of Grade VIII students of SMP N 1 Srandakan in Bantul even in the 2015/2015 academic year?

Based on the above problem formulation, this study aims to find out the following matters:

1. To find out whether or not there are differences in mathematics learning outcomes using the NHT learning model against mathematics learning outcomes of students who use direct learning models in class VIII students of SMP N 1 Srandakan Bantul Regency even semester of the 2015/2016 academic year.

2. To find out which is more effective between the NHT type of cooperative learning model and the direct learning model of the mathematics learning outcomes of Grade VIII students of SMP N 1 Srandakan in Bantul even in the 2015/2016 academic year.

\section{METHODS}

This type of research is experimental research, where there are 1 experimental classes and 1 control class. The experimental class was treated using the NHT learning model. While the control class was treated using the direct learning model. The effect of these treatments can be known from the results of student mathematics learning. According to Sukardi (2003: 183), a broad understanding of research design is all the processes required in planning and conducting research. The design in this study used the Posttest Only Control Group Design with Random Subjects. The design of this study is illustrated in Table 2.

Table 2. Study design randomized Subjects Posttest Only Control Group Design

\begin{tabular}{|c|c|c|c|}
\hline & Group & Bound Variable & Postest \\
\hline$(\mathrm{R})$ & Experiment & $\mathrm{X}$ & $Y_{2}$ \\
\hline$(\mathrm{R})$ & Control & - & $Y_{2}$ \\
\hline
\end{tabular}

Source: Sukardi (2003: 185)

Information :

$\mathrm{R}$ : random

$\mathrm{X}$ : treatment using the NHT type cooperative learning model

Y2: mathematics learning achievement test

This research was conducted at SMP N 1 Srandakan Bantul Regency. When the research was conducted in the even semester of the academic year 2015/2016 with the subject of limas. The population in this study were all students of class VIII SMP N 1 Srandakan even semester 2015/2016 academic year with a total of 190 students consisting of classes VIII A, VIII B, VIII C, VIII D, VIII E and VIII F. This study uses techniques random sampling, where all members of the population are given the same opportunity to be selected as sample members. Sample classes are taken by the lottery. After drawing the population consisting of six classes, two samples were obtained consisting of one class as the experimental class (class VIII D) and one control class (VIII E). Meanwhile, outside the sample 
class VIII C was obtained as an instrument trial class. The variables in this study are learning models and learning outcomes.

Data collection techniques used are documentation techniques and test methods. The documentation technique is used to obtain data from respondents. In this study, documents were obtained from the archives of daily test scores. The daily math scores of cube material and even semester blocks of class VIII are considered as the initial abilities of each student. While this test technique is used to obtain data on mathematics learning outcomes of Grade VIII students who are in the experimental class. In this study, the test used was a mathematics learning outcomes test (posttest) given to the experimental class with the treatment of the NHT learning model and the control class that was treated with the direct learning model. To obtain data on the effectiveness of the use of the NHT type of cooperative learning model on mathematics learning outcomes for students of class VIII SMP N 1 Srandakan Bantul Regency even semester 2015/2016, the research instrument in the form of tests was used, namely the post-test of mathematics learning outcomes. This test is in the form of multiple-choice with 4 alternative answers, namely a, b, c, and d. If the answer is correct, then a score of 1 is given, and if the answer is incorrectly given a score of 0 . To avoid deviating from the subject matter, a study test post is made, a test item, and a test item test results learn math.

Test instruments that have been arranged can be tested on the instrument trial class, namely class VIII C. After the test is tested, the next step is to analyze the test items of the test. The first analysis is the validity test analysis using the product-moment correlation formula. To determine the validity of the content using expert judgment (lecturer review). After compiling the test instruments and have been reviewed by Mrs. Harina Fitriyani M.Pd, then tested on the instrument test class. A trial test is conducted to find out whether the test items are feasible to use, namely valid and reliable items.

Based on the results of the analysis of the validity test with a significance level of 5\%, it was found that there were 15 questions about the validity of the test results and 10 questions were dropped. Items that are valid are used in research, while those that are invalid are declared to be invalid subsequently not used in research. The second analysis is the differentiation test using the discrimination index formula. The items that have the power criteria that can be used in this study are 15 items. The minimum power differential criteria are sufficient ( $D>0.20$ ). The third analysis is the reliability test using the Kuder Richardson-20 (KR-20) formula. The prerequisite test analysis uses the normality test with the Chi-Square test and homogeneity test with the Bartlett test. While the hypothesis test uses the t-test of two parties and one party.

\section{RESULTS AND DISCUSSION}

Based on the research that has been carried out obtained data in the form of initial abilities and student mathematics learning outcomes.

\section{Initial Ability}

The initial ability score was obtained from the daily mathematical test scores with cube and block material in class VIII D and VIII E SMP N 1 Srandakan Bantul Regency and obtained the initial mathematical ability values as produced in Table 3.

Table 3. Summary Descriptions of Initial Ability Values

\begin{tabular}{|l|c|c|}
\hline \multicolumn{1}{|c|}{ Class } & $\begin{array}{c}\text { Experimentation } \\
\text { Class (VIII D) }\end{array}$ & $\begin{array}{c}\text { Control class } \\
\text { (VIII E) }\end{array}$ \\
\hline The highest score & 65,00 & 65,00 \\
\hline Nlai Lowest & 22,50 & 22,50 \\
\hline Average & 40,28 & 41,40 \\
\hline $\begin{array}{l}\text { Standard } \\
\text { Deviation }\end{array}$ & 10,84 & 11,30 \\
\hline Variance & 117,57 & 127,75 \\
\hline Lots of Data & 32 & 32 \\
\hline
\end{tabular}


The normality test aims to determine whether the initial ability of the experimental class and the control class are normally distributed or not. A summary of the results of the initial ability normality test is presented in Table 4.

Table 4. Summary of the Normality Test Results Initial Capability

\begin{tabular}{|l|l|l|}
\hline Class & \multicolumn{1}{|c|}{$\chi_{\text {count }}^{2}$} & \multicolumn{1}{c|}{$\chi_{\text {table }}^{2}$} \\
\hline Experiment & 2,8107 & 9,4877 \\
\hline Control & 2,7388 & 9,4877 \\
\hline
\end{tabular}

Based on the calculation of normality test Table 4 experimental class data with a significant level of $5 \%$ and $\mathrm{df}=4$, it can be seen that $\chi_{\text {count }}^{2}<\chi_{\text {table }}^{2}$ which means that the experimental class has normally distributed data. Normality test conducted in the control class with a significant level of $5 \%$ and $\mathrm{df}=4$, it can be seen that $\chi_{\text {count }}^{2}<\chi_{\text {table }}^{2}$ which means that the control class has normally distributed data.

A homogeneity test is carried out to investigate whether both samples have the same or homogeneous variance. The test used to test the similarity of sample variance is the Bartlett test. The homogeneity test calculation process is performed using the Microsoft Excel program.

The data used to conduct this test is data from the results of the initial mathematical abilities of students in class VIII D and class VIII E can be seen in Table 5.

Table 5. Summary of Homogeneity Test Results Initial Ability Score

\begin{tabular}{|c|c|}
\hline$\chi_{\text {count }}^{2}$ & $\chi_{\text {table }}^{2}$ \\
\hline 0,157 & 3,8415 \\
\hline
\end{tabular}

The test criteria for homogeneity tests are if $\chi_{\text {stat }}^{2}<\chi_{\text {table }}^{2}$, hence the variance of the sample is homogeneous. Based on Table 5 above it appears that the value $\chi_{\text {count }}^{2}=0,157$ and $\chi_{\text {table }}^{2}=$ 3,8415 , then $\chi_{\text {count }}^{2}<\chi_{\text {tabel }}^{2}$ at a significant level $\alpha=5 \%$ and $\mathrm{dk}=1$, so that the variance of students' initial ability data in the study is homogeneous.

A summary of the results of the two-party hypothesis test of the initial ability scores of the experimental class and control class students can be seen in Table 6 .

Table 6. Summary of Results of the Two-Party Hypothesis Test Initial Values

\begin{tabular}{|c|c|}
\hline $\boldsymbol{t}_{\text {count }}$ & $\boldsymbol{t}_{\text {table }}$ \\
\hline 0,2874 & 1,99897 \\
\hline
\end{tabular}

Based on Table 6 , the value of $t_{\text {count }}<t_{\text {table }}$ is obtained, then $\mathrm{H}_{0}$ is accepted, which means that there is no difference in the initial ability scores of students in class VIII D and VIII E SMP N 1 Srandakan, Bantul Regency in the academic year 2015/2016.

\section{Mathematics Learning Outcomes}

Description of student learning outcomes in mathematics after the experiments are presented in Table 7.

Table 7. Summary Description of Mathematics Learning Outcomes

\begin{tabular}{|l|c|c|}
\hline Parameter & $\begin{array}{l}\text { Experimentation } \\
\text { Class }\end{array}$ & $\begin{array}{l}\text { Control } \\
\text { Class }\end{array}$ \\
\hline The number of students & 32 & 32 \\
\hline The highest score & 100,00 & 93,33 \\
\hline Lowest Value & 53,33 & 33,33 \\
\hline Average & 74,58 & 65,21 \\
\hline Standard Deviation & 13,32 & 15,93 \\
\hline Variance & 177,52 & 253,72 \\
\hline
\end{tabular}


The normality test aims to determine whether the value of mathematics learning outcomes of experimental and control class students is normally distributed or not. A summary of the results of normality scores for students' mathematics learning outcomes is presented in Table 8.

Table 8. Summary of Normality Test Results Mathematics Learning Outcomes

\begin{tabular}{|c|c|c|}
\hline Class & $\chi_{\text {count }}^{2}$ & $\chi_{\text {table }}^{2}$ \\
\hline Experiment & 3,2460 & 7,8147 \\
\hline Control & 1,3518 & 7,8147 \\
\hline
\end{tabular}

Based on the calculation of normality test Table 8 experimental class data with a significant level of $5 \%$ and $\mathrm{df}=3$, it can be seen that $\chi_{\text {count }}^{2}<\chi_{\text {table }}^{2}$ which means that the experimental class has normally distributed data. Normality test conducted in the control class with a significant level of $5 \%$ and $\mathrm{dk}=3$, it can be seen that $\chi_{\text {count }}^{2}<\chi_{\text {table }}^{2}$ which means that the control class has normally distributed data.

A homogeneity test is carried out to investigate whether both samples have the same or homogeneous variance. The test used to test the similarity of sample variance is the Bartlett test. The homogeneity test calculation process is performed using the Microsoft Excel program.

The data used to conduct this test is data from the grades of students learning outcomes in class VIII D and class VIII E can be seen in Table 9.

Table 9. Summary of Homogeneity Test Results Mathematics Learning Outcomes

\begin{tabular}{|c|c|}
\hline$\chi_{\text {count }}^{2}$ & $\chi_{\text {table }}^{2}$ \\
\hline 3,4623 & 3,8415 \\
\hline
\end{tabular}

The test criteria for homogeneity tests are if $\chi_{\text {count }}^{2}<\chi_{\text {table }}^{2}$, then the variance of the sample is homogeneous. Based on Table 9 above it appears that the value $\chi_{\text {count }}^{2}=3,4623$ and $\chi_{\text {table }}^{2}=$ 3,8415 , then $\chi_{\text {count }}^{2}<\chi_{\text {table }}^{2}$ at a significant level $\alpha=5 \%$ and $\mathrm{dk}=1$, so the data variance of students' mathematics learning outcomes in research is homogeneous.

Hypothesis Test of Two Parties Learning Outcomes of Mathematics

$\mathrm{H}_{0}: \mu_{1}=\mu_{2}$

$\mathrm{H}_{1}: \mu_{1} \neq \mu_{2}$

With:

$\mathrm{H}_{0}$ : there is no difference between students 'mathematics learning outcomes using NHT type cooperative learning models against students' mathematics learning outcomes using direct learning models in class VIII students of SMP N 1 Srandakan, Bantul Regency, even semester of the 2015/2016 school year.

$\mathrm{H}_{1}$ : there is a difference between students 'mathematics learning outcomes using the NHT type of cooperative learning model against students' mathematics learning outcomes using direct learning models in class VIII students of SMP N 1 Srandakan, Bantul Regency, even semester of the 2015/2016 school year.

A summary of the results of the two-party hypothesis test on mathematics learning outcomes can be seen in Table 10 .

Table 10. Summary of Hypothesis Test Results of Two Parties Mathematical Learning Outcomes

\begin{tabular}{|c|c|}
\hline $\boldsymbol{t}_{\text {count }}$ & $\boldsymbol{t}_{\text {table }}$ \\
\hline 2,3802 & 1,99897 \\
\hline
\end{tabular}

Based on table 10 above with a significance level of 5\% and a degree of freedom 62, values are obtained $t_{\text {count }}<t_{\text {table }}$, then $\mathrm{H} 0$ is rejected, which means that there are differences in mathematics learning outcomes between students who use the NHT type cooperative learning model and students who use a direct learning model towards mathematics learning outcomes for students of class VIII of SMP N 1 Srandakan, Bantul Regency, even semester of the 2015/2016 school year.

One-Party Hypothesis Testing Learning Outcomes of Mathematics 
$\mathrm{H}_{0}: \mu_{1}=\mu_{2}$

$\mathrm{H}_{1}: \mu_{1}>\mu_{2}$

With:

$\mathrm{H}_{0}$ : The NHT learning model is equally effective as the direct learning model of the mathematics learning outcomes of Grade VIII students of SMP N 1 Srandakan Regency of Bantul, even semester of the academic year 2015/2016.

$\mathrm{H}_{1}$ : The NHT type of cooperative learning model is more effective than the direct learning model of the mathematics learning outcomes of Grade VIII students of SMP N 1 Srandakan, Bantul Regency, even semester 2015/2015 academic year.

A summary of the results of the one-party hypothesis test on mathematics learning outcomes can be seen in Table 11 .

Table 11. Summary of Results of One-Party Hypothesis Test Results of Mathematical Learning

Outcomes

\begin{tabular}{|c|c|}
\hline $\boldsymbol{t}_{\text {count }}$ & $\boldsymbol{t}_{\text {table }}$ \\
\hline 2,3802 & 1,66980 \\
\hline
\end{tabular}

Based on Table 11 obtained values $t_{\text {ount }}<t_{\text {table }}$, then $\mathrm{H}_{0}$ is rejected, which means that the NHT type of cooperative learning model is more effective than the direct learning model of mathematics learning outcomes for students of class VIII of SMP N 1 Srandakan, Bantul Regency, even semester 2015/2015 academic year.

\section{CONCLUSION}

Based on the results of research and discussion that has been described, then some research conclusions can be drawn as follows:

1. There is a difference in mathematics learning outcomes between students who use the NHT type of cooperative learning model and students who use the direct learning model of mathematics learning outcomes for students of class VIII SMP N 1 Srandakan Bantul Regency, even semester 2015/2015 academic year.

2. 2. This is indicated by the two-party hypothesis test with a significant level of $5 \%$ and a degree of freedom 62 , then the value obtained $t_{\text {count }}=2,3802$ and $t_{\text {table }}=1,99897$, so that $t_{\text {count }}>$ $t_{\text {table }} \mathrm{H}_{0}$ is rejected and $\mathrm{H}_{1}$ is accepted.

3. The NHT type of cooperative learning model is more effective than the direct learning model of the mathematics learning outcomes of Grade VIII students of SMP N 1 Srandakan Regency, Bantul, even semester 2015/2015

4. This is indicated by the results of the one-party hypothesis test with a significant level of $5 \%$ and degrees of freedom 62, then obtained $t_{\text {count }}=2.3802$ and $t_{\text {table }}=1.66980$, so $t_{\text {count }}>t_{\text {table }} \mathrm{H}_{0}$ is rejected and $\mathrm{H}_{1}$ is accepted.

\section{REFERENCES}

Ahmadi, Lif Khoiru dkk. 2011. Strategi Pembelajaran Sekolah Terpadu. Jakarta: Prestasi Pustaka.

Huda, Miftahul. 2012. Cooperatif Learning. Yogyakarta: Pustaka Pelajar.

Suherman, Erman, dkk. 2003. Strategi Pembelajaran Matematika Kontemporer. Yogyakarta: Universitas Pendidikan Indonesia.

Sukardi. 2009. Metodologi Penelitian Pendidikan. Jakarta: PT Bumi Aksara.

Suprihatiningrum, Jamil. 2013. Strategi Pembelajaran Teori \& Aplikasi._Yogyakarta: Ar-Ruzz Media.

Rusman. 2013. Model- Model Pembelajaran Mengembangkan Profesionalisme Guru. Jakarta: Rajawali Pers.

Undang-undang Republik Indonesia No 20 Tahun 2003 Bab 1 Pasal 1 Sistem Pendidikan Nasional. 